ВРЕДНОВАҢЕ КАРАКТЕРИСТИКА КРОВНИХ ВРТОВА У ОКВИРУ СЕРТИФИКАЦИЈЕ ОДРЖИВЕ ИЗГРАДЫЕ

\title{
EVALUATION OF GREEN ROOF CHARACTERISTICS IN GREEN BUILDING ASSESSMENT
}

\author{
Мирјана Секулић*, Бојана Станковић**, Милица Јовановић Поповић*** \\ рад примљен: децембра 2013, рад прихваћен: децембра 2013.
}

\section{Апстракт}

Методологија вредновања зграда по разноврсним критеријумима одрживе изградње већ увелико узима маха како у иностраној, тако и у домаћој пракси. Ова методологија се спроводи путем различитих система сертификације, сложених механизама процене који укључују бројне критеријуме одрживости, како еколошке, тако и економске и друштвене. Кровни вртови представљају један од императива савремене изградње која тежи да се класификује као одржива и верификује одређеним сертификатом. Ова парадигма заснована је, пре свега, на њиховим својствима која доприносе побољшању одрживих карактеристика бројних аспеката проблематике грађења, међу којима су уштеда енергије и воде, еколошка равнотежа грађене средине, квалитет непосредног окружења итд. Критеријуми којима се вреднује одрживост кровних вртова и њихов допринос квалитету зграде, саставни су део свих ових система, али се њихово формулисање, из кога произилази и начин примене при процени, разликује међу системима. У раду је приказана анализа критеријума везаних за проблематику кровних вртова и њиховог доприноса квалитету зграда три карактеристична система сертификације: LEED, BREEAM и CASBEE. Ови системи одабрани су пре свега због карактеристика методологије процене, али и заступљености примене и перспективе примене у домаћој средини. Закључци изведени из поређења ових критеријума пружају увид у најважније аспекте планирања и изградње кровних вртова од значаја за целокупну процену одрживости зграда.

Кључне речи: кровни врт, сертификација одрживе градне, LEED, BREEAM, CASBEE

\begin{abstract}
Methodology of building evaluation based on green building characteristics is rapidly gaining momentum, mainly in foreign, but also in domestic building practice. This methodology is being carried out through different Green Building Certification Systems, which are complex evaluation mechanisms based on numerous criteria of sustainability, addressing both ecological issues, but also economic and social ones. Green roof represents one of the "must have" features of contemporary buildings aiming to gain green label. This paradigm is based on their numerous characteristics which contribute to different aspects of building sustainability, among which are savings in energy and water consumption, but also ecological balance and quality of built environment. Criteria used for evaluation of green roof solutions and their overall contribution to the building, are integral part of all of the mentioned certification systems, but the way they are structured and formulated inside each system varies significantly, hence causing differences in evaluation results. This paper presents the analysis of green roof related criteria of three characteristic green building certification systems: LEED, BREEAM and CASBEE. These systems are chosen primarily because of the different evaluation methodology, but also because of their market prevalence and perspectives of usage in the domestic practice. Conclusions driven from these analyses and comparisons provide insight into main aspect of green roof planning and construction which are relevant for the overall building sustainability assessment.
\end{abstract}

Key words: green roof, Green Building Certification Systems, LEED, BREEAM, CASBEE
Системи сертификације' зграда по критеријумима одрживе изградње су сложени механизми за процену квалитета зграде, по сету бројних критеријума везаних за одрживе принципе грађења, и ефикасно допунско средство законске регулативе у развоју праксе одрживе изградње

(Cole, 2003). Иако се процесом енергетске сертификације (JovanovićPopović et al, 2008), којим се предвиђа

увођење обавезних енергетских пасоша, као и новим правилником 0 енергетској ефикасности, пооштравају и редефинишу критеријуми везани за енергетску ефикасност и уводи нова пракса у процес изградње, недостају методи за детаљнију процену еколошких утицаја изградње, нарочито са аспекта грађевинских материјала (Jovanović-Popović et al., 2009). Teорија одрживог грађења показује да су у процени одрживости решења, као сложеног и вишедимензионалног

проблема, најпогодније методе вишекритеријумске анализе. Системи сертификације зграда представљају начин свеобухватне процене еколошких карактеристика зграда по дефинисаном сету критеријума, а до њихове појаве није ни било објективног и адекватног начина да се истовремено процени испуњеност

бројних еколошких захтева према јасно дефинисаним критеријумима и да се пружи преглед оствареног учинка (Cole, 2003).

\footnotetext{
* Др Мирјана Секулић, д.и.п.а., ФТН-Универзитет у Новом Саду, Департман за архитектуру и урбанизам, sekulic.mirjana55@gmail.com

** Бојана Станковић, дипл.инж.арх. мастер - докторанд, Архитектонски факултет у Београду, stankovicarch@gmail.com

***Проф. др Милица Јовановић Поповић, д.и.а., Архитектонски факултет у Београду, milicajp@arh.bg.ac.rs

1 Системи сертификације зграда, односно Green Building Certification Systems, или Building Environmental Assessment Methods, представљају алате највишег степена еколошке процене (Ignjatović et al, 2011), којима, као доминантно тржишним алатима, основни циљ представља стимулисање развоја тржишта у правцу одрживе изградње, што се постиже једноставном структуром система и прегледним сетом информација које произилазе из процеса сертификације.
} 
Вегетабилни кровни систем уопштени је израз који се користи када се говори о свим типовима кровног зеленила (Crnčević i Sekulić, 2012). Најкраћи опис вегетабилног кровног система је кровна конструкција прекривена вегетацијом која егзистира на њеној површини. Код нас је заживела синтагма кровни врт и препоручујемо да се усвоји у значењу вегетабилног кровног система, као краћи, функционалнији и као израз који већ има широку употребу и у лаичкој и у професионалној свести. Кровни врт је сложена биофизичка структура која представља отворени простор, врт, који је скоро исти као и на терену, али је изграђен преко конструкције (одвојен од тла грађевином или неком другом структуром) и може да буде на висини или на коти терена (Sekulić, 2013). Критеријуми који су директно везани за проблематику кровних вртова постоје у свим системима сертификације, а груписани су на различите начине у зависности од тога на који аспект квалитета решења утичу.

\section{Карактеристике анализираних сертификационих система}

Процес сертификације подстиче еколошку свест у процесу грађења и поставља јасне смернице грађевинској индустрији у циљу одрживе изградње, тако што пружа оквир за структурисањебазеподатакаувези са одрживимпринципима грађења и даје реалну процену учинка и карактеристика зграда (Ding, 2008). Такође, подстицање тржишне утакмице кроз дефинисан оквир циљева и вредновања квалитета битно утиче на постизање врхунских еколошких перформанси (best practices), које често надмашују оквире законске регулативе (Larsson, 2000). Кроз пооштравање критеријума ових система постоји могућност утицаја и на развој законске регулативе, нарочито тамо где она озбиљно заостаје за потребама одрживог развоја изградње. Оно што је заједничко свим овим системима је (Cole, 2003):

- структура, која се заснива на постојању одређених критеријума,

- систем поентирања,

- рангирање пројекта према освојеном броју поена и додела сертификата.

На светском тржишту је данас у употреби мноштво различитих система сертификације, како појединачних, националних, тако и оних интернационалног карактера. Први систем сертификације, BREEAM (Building Research Establishment Environmental Assessment Method) појавио се 1990. год. у Великој Британији. Након тога је уследило ширење и усавршавање овог система али и развој нових система широм света. Најраспрострањенији такав систем развио се у оквиру америчког Савета одрживе изградње (U.S. Green Building Council, USGBC) формулисан као LEED (Leadership in Energy and Environmental Design). По тврдњама многих аутора, LEED систем представља најзаступљенији систем сертифкације широм света (Papadopoulos, Giama, 2007; Wu, Low, 2010). У процесу његовог креирања анализирани су многи други системи сертификације, а међу њима и BREEAM, са којим LEED систем има највише сличности. Прва верзија LEED система одобрена је 1998. год. (Version 1.0), након чега је покренут пилот програм чији је циљ био препознавање мана и унапређење система кроз пробне сертификације. Редовне ревизије система врше се на сваке две године, а пракса да се систем прво стави на увид јавности и јавну расправу, након чега следи још један круг ревизије, постала је обавезна. Сам процес сертификације у LEED систему врши се кроз процедуру регистрације пројекта и подношења одређених формулара (credit forms) на званичној интернет страници, и наплаћује се по дефинисаним тарифама, које зависе од типа и/или величине пројекта. LEED систем је у претходној деценији доживео експанзију (број сертификованих пројеката је са 1.000 крајем 2003. год. порастао на 10.000 крајем 2008. год.) и убрзано се шири на разна светска тржишта, међу којима су најзначајнија свакако кинеско и саудиарабијско, али и јужноамеричко (Бразил, Мексико) и европско (Италија је у потпуности преузела LEED систем). Такође, у многим земљама LEED је присутан паралелно са националним системима сертификације (Канада, Немачка, Француска, Шпанија).

Покушај креирања интернационалног система сертификације, као и интернационализација постојећих локалних система и даље представља изазов за ширење праксе одрживе изградње. Неки аутори тврде да је ефикасније препознати пожељне карактеристике процене међу већ постојећим алатима и додатно дефинисати локалне специфичности у оквиру одабраног система, него креирати нови систем намењен широкој употреби (Wen, Y. C., 2005).

у оба поменута система, као и у већини осталих који су у широкој употреби, постоји неколико група критеријума, у зависности од тога који аспект проблема одрживе изградње третирају. Тако у оквиру LEED система (прецизније LEED for New Construction and Major Renovation, скраћено LEED-NC) постоји шест категорија:

- одржив третман земљишта (sustainable site development, SS);

- yumeda воде (water savings, WE);

- енергија и атмосффера (energy and atmosphere, EA);

- материјали и сировине (materials and resources, MR);

- квалитет унутрашњег ваздуха (indoor environmental quality, IEQ);

- $\quad$ иновације у дизајну (innovation in design, ID).

У свакој категорији постоји одређен број обавезних кредита (prerequisits) чије је критеријуме неопходно испунити да би се добио сертификат. Ти кредити се не вреднују поенима. Остали кредити се, у зависности од степена испуњености критеријума, вреднују одређеним бројем поена. Описана структура је илустрована чек-листом (С. 1):

У BREEAM систему постоји 10 категорија и укупан сличан број критеријума као и у LEED систему: Управљање пројектом (Management), Здравље (Health \& Wellbeing), Eнергuja (Energy), Tрансnорm (Transport), Вода (Water), Meтеријали (Materials), Omnad (Waste), Третман земљишта и екологија (Land Use \& Ecology), Загађење (Pollution), Иновација (Inovation). У оба 


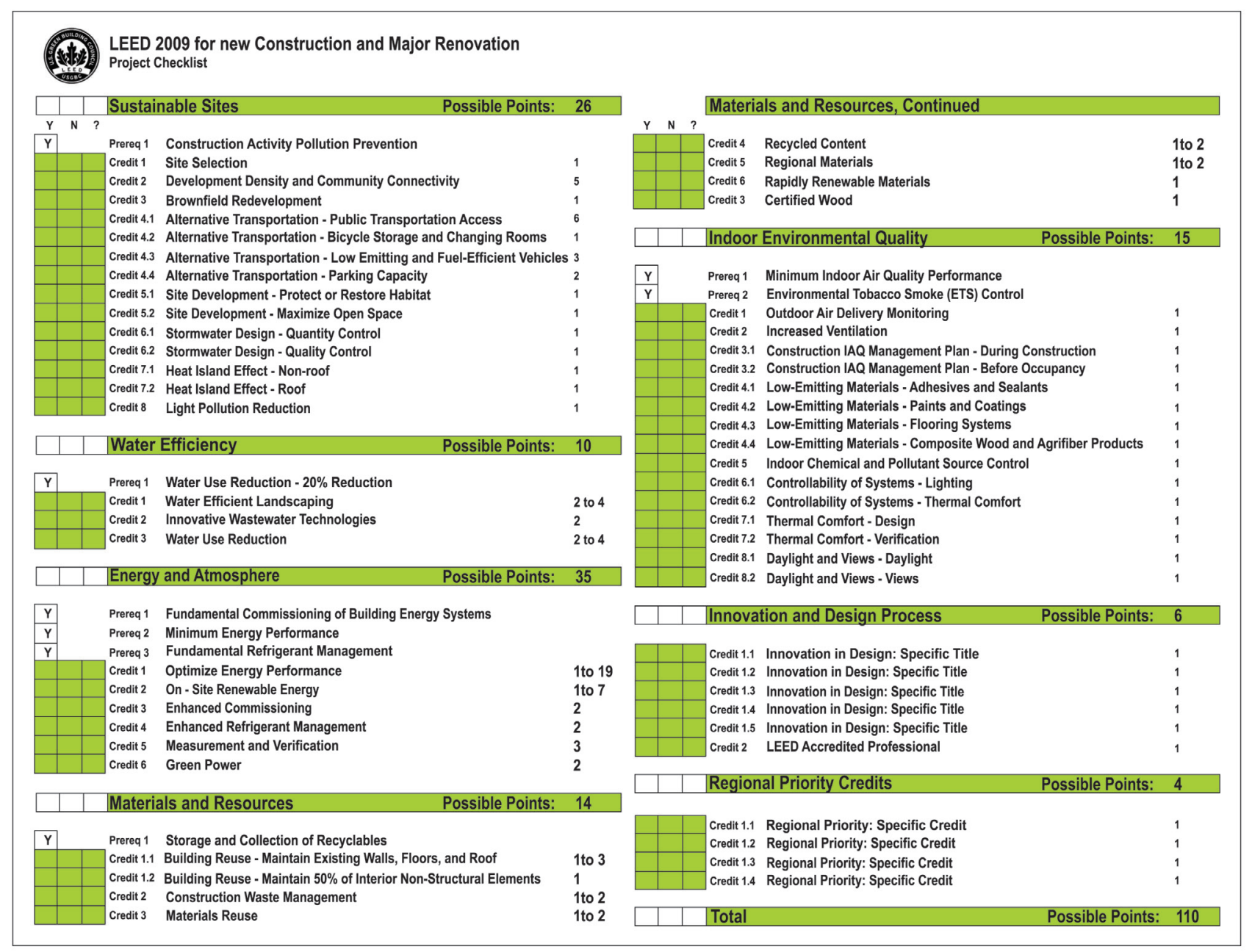

Сл. 1.

Структура и групе критеријума LEED-NC система Fig. 1.

Structure and criteria categories of LEED-NC system

система је третиран сличан опсег тема одрживе изградње објеката, а основна разлика лежи у начину вредновања испуњености постављених критеријума. Док код LEED система пројектантски тим бира комбинацију критеријума које ће задовољити како би у збиру добили довољан број поена за жељени сертификат (основни, бронзани, сребрни, златни, платинасти), што значи да неке може потпуно да занемари, код BREEAM система, за сваки критеријум постоји праг испуњености за сваки степен сертификације (основни, добар, врло добар, одличан).

CASBEE систем је развијен у Јапану и намењен је првенствено Јапанском тржишту. Rазвијао се кр0з заједничку иницијативу од стране представника индустрије и власти у области грађења. Од 2001. год. кренули су са оснивањем савеза одрживих зграда коме су се придружиле разне истраживачке организације, са идејом да направе сертификациони систем којим би се истакле зграде са изузетним карактеристикама одрживости, и тиме дао пример и подстицај за развој одрживих пракси изградње.
Систем је уједно требало да буде једноставан за употребу и примељив на разне типове пројеката, узимајући у обзир локалну проблематику и карактеристике градње. Развијена је јединствена методологија вредновања која се заснива на идеји процене односа између доприноса зграде квалитету окружења (Q, Building Environmental Quality \& Performance) са једне, и оптерећења која зграда намеће окружењу (L, Building Environmental Loadings) са друге стране. Сликовито објашњено, посматрајући зграду као затворену целину, прве карактеристике, квалитет зграде, односе се на односе који владају унутар те целине, а друге, оптерећење наметнуто окружењу, односе се на утицај првих карактеристика изван граница те затворене целине (Сл. 2). Постигнут ниво сертификације одређује BEE (Building Environmental Efficiency) индикатор, који се добија као количник суме поена остварених у категорији $\mathrm{Q}$ и суме поена оставрених у категорији $\mathrm{L}$ (BEE= $Q / L)$, што значи да што је квалитет зграде већи, а оптерећење наметнуто окружењу мање, вредност ВЕЕ индикатора се повећава, а тиме и остварени ниво сертификације. 

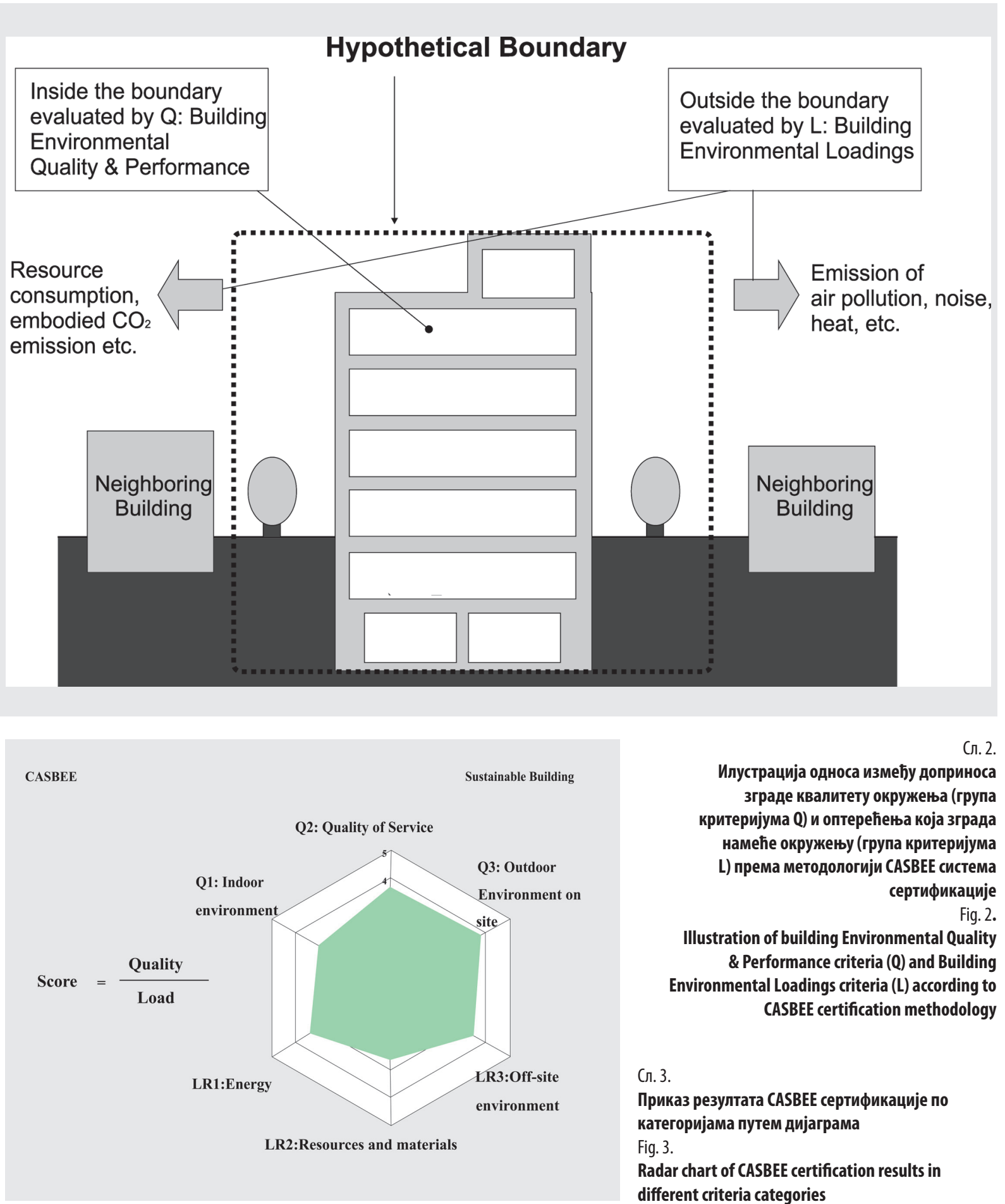

Сл. 2.

Илустрација односа између доприноса зграде квалитету окружења (група критеријума Q) и оптерећења која зграда намеће окружењу (група критеријума L) према методологији CASBEE система сертификације Fig. 2.

Illustration of building Environmental Quality

\& Performance criteria (Q) and Building Environmental Loadings criteria (L) according to CASBEE certification methodology

Сл. 3.

Приказ резултата CASBEE сертификације по категоријама путем дијаграма

Fig. 3.

Radar chart of CASBEE certification results in different criteria categories

\section{Критеријуми LEED система релевантни за проблематику кровних вртова}

Сертификат се састоји од дијаграма (Сл. 3) на којима је графички јасно представљен резултат вредновања кроз различите критеријуме. Постоји шест главних категорија у које су груписани критеријуми по којима се оцењује зграда, где се по 3 групе односе на квалитет зграде $(Q 1,02,03)$ и на оптерећења наметнута окружењу (LR1, LR2, LR3).
Критеријуми везани за одрживост кровних вртова у LEED систему налазе се првенствено у оквиру категорија: Одрживост локације (SS), Уштеда воде (WE) и Енергија и атмосфера (ЕА). Иако неки аутори, као Обри Хек (Hake, 2007), наводе да се и критеријуми из категорије Материјали и ресурси (МА), везани за проценат рециклираног 
садржаја у примењеним материјалима, као и за примену материјала локалног порекла, могу сматрати релевантним за проблематику кровних вртова, сматрамо да је акценат проблематике кровних вртова, ипак, ван ове категорије, пошто се проблематика материјализације односи подједнако на све аспекте изградње и сва примењена решења. Кроз категорију Одрживости локације вреднује се одрживо планирање и третман јавних, отворених и пејзажно урбаних структура, утицај на успоравање одлива атмосферских вода и смањење ефекта урбаних топлотних острва (УТ0). Специфични критеријуми који се односе на кровне вртове су следећи:

- Заштита постојећих или поновно успостављане пејзажно-урбаних структура (SS 5.1: Site Development: Protect or Restore Habitat) је критеријум којим се дефинише опсег заштите постојећег биљног покривача на локацији, односно прописује минимални проценат површине парцеле који мора бити под биљним покривачем, где се у случају густо изграђеног градског ткива кровни вртови рачунају као равноправне пејзажно-урбане структуре.

- Повећане отворених простора (SS 5.2: Site Development: maximize open space) се односи на повећање процента отворених површина, у које се убрајају и кровни вртови, у односу на максималне дозвољене проценте заузетости парцеле.

- Квантитет атмосферских вода (SS 6.1: Stormwater Design: Quantity Control) вреднује стратегије којима се смањује проценат непорозних површина на парцели, и тиме успорава одлив атмосферских вода, међу којима је и стратегија уградње кровних вртова.

- Квалитет атмосферских вода (SS 6.2: Stormwater Design: Quality (ontrol) вреднује решења кровних вртова као стратегију за пречишћавање атмосферских вода кроз инфилтрацију.

- Eфекат топлотних острва - ван крова (SS 7.1: Hеat Island Effect: Non-Roof) критеријум је кроз који се подстиче смањење површина на парцели (пре свега елемената партера) које доприносе стварању ефекта топлотних острва, где се кровни вртови вреднују као једно од решења наткривања паркинга.

- Eфекат топлотних острва - крова (SS 7.2: Heat Island Effect: Roof) је критеријум најдиректније везан за примену кровних вртова, пошто је дефинисан захтев да 50\% кровне површине буде решено као кровни врт, а додатни поени ${ }^{2}$ су могући ако се целокупна кровна површина реши на овај начин.

- Пејзажно уређење које на ефикасан начин користи воду (WE 1: Water Efficient Landscaping) је критеријум који дефинишесмањењепотрошњепијаћеводезазаливање за 50\% (2 поена), или у потпуности елиминише потребу

\footnotetext{
2 Додатни поени су поени који се стичу кроз посебну категорију Иновације у дизајну (Innovation in Design), кроз опцију Изузетног учинка (Exemplary Performance) који постоји као опција за одређене критеријуме, уколико степен њихове испуњености надмашује основне захтеве.
}

за заливањем (додатна 2 поена) избором биљних врста које не захтевају додатно заливање (вегетација адаптирана локалним климатским условима).

- Повећање енергетске ефикасности (ЕA 1: Optimize Energy Performance) је критеријум кроз који се вреднују све стратегије које доприносе побољшању енергетске ефикасности и носи највише поена од свих критеријума који постоје у LEED систему (и до 21 поен за неке верзије система). (тепен уштеде, од кога зависи и вредновање, одређује се на основу симулације енергетских својстава зграде и поређења резултата симулације са базним случајем дефинисаним стандардом. Кроз симулацију се показује ефикасност свих примењених решења, па тако и уштеде настале као резултат примене кровног врта, пре свега због побољшаних термичких карактеристика тог дела термичког омотача, али и утицаја који потичу од смањења температуре ваздуха у зони крова, што може утицати на функционисање и енергетску ефикасност HVAC уређаја чије се спољне јединице налазе у зони кровних вртова, као и на већу ефикасност фотонапонских панела, као што је елаборирано у раду Мартина Келера (Köhler, 2007).

Сви наведени критеријуми из категорије Одржив третман земљишта (SS) вреднују се са по једним поеном, што значи да је одговарајућом применом кровних вртова могуће освојити укупно 6 поена. Уз максимална 4 поена у категорији Уштеда воде (WE), то чини 10\% од укупног броја могућих поена. Овде нису укључени поени који би били добијени у склопу поена за уштеду енергије $(E A)$, пошто је процена утицаја кровних вртова на енегретску ефикасност још увек недовољно истражена кроз енергетско моделовање (Ansel, 2004), али на основу резултата истраживања у локалној средини (Sekulić, 2013: 269-271) могу се узети у обзир уштеде од 5\% у потребној енергији за грејање и до $10 \%$ у потребној енергији за хлађење, што у збиру доноси максимална 3 поена у оквиру EA1 категорије. Закључак је да утицај кровних вртова на резултат сертификације прелази $10 \%$, што је значајно с обзиром на комплексност процене $и$ број третираних принципа одрживе изградње.

Као један од закључака истраживања које је за циљ имало дефинисање посебног сета критеријума везаних за проблематику кровних вртова у оквиру LEED система (Hake, 2007), јавља се и одбацивање могућности да се проблематика кровних вртова и критеријуми који би вредновали одрживост конкретних решења процењују одвојено од анализе и вредновања целокупног објекта, као део независног система, или подсистема у оквиру LEED-a (у истраживању је био предложен подсистем LEED for Green Roofs). Такође, иако је закључак да у LEED систему довољно критеријума покрива проблематику кровних вртова, поставља се питање да ли је, и поред тога што кроз освајање тих критеријума кровни вртови доприносе освајању поена и добијању сертификата, њихова одрживост заиста добро процењена, односно да ли је у неким случајевима пренебрегнута контрадикторност међу њима. Тако се фаворизовањем и инсистирањем на вегетацији која се 
заснива на локалним биљним врстама, које захтевају дубљи слој субстрата и самим тим више коштају, занемарују решења екстензивних кровних вртоваз, која у неким случајевима представљају погодније решење, а због тога што су јефтинија могу определити инвеститоре за улагање у већу површину под кровним вртовима. Један од примера пројеката чији се основни архитектонски концепт заснива на примени кровног врта, који уједно постаје и један од основних примењених принципа одрживе изградње, што је потврђено кроз LEED Gold сертификат, је пројекат новог седиштаํㅜ организације за заштиту дивљине (Wildlife Conservation Society) смештеног уз северну ивицу њујоркшког зоолошког врта у Бронксу (С. 4 и 5).

\section{Критеријуми BREEAM система релевантни за проблематику кровних вртова}

Иако и у BREEAM систему кровни вртови могу дати допринос сертификацији кроз критеријуме везане за смањење потрошње пијаће воде (Wat 01) и смањење емисије $\mathrm{CO}_{2^{\prime}}$ кроз повећање енергетске ефикасности (Ene 01), у оба ова критеријума вредновање доприноса кровних вртова је посредно, а самим тим је тешко говорити о дефинисању тачног броја поена који се могу приписати кровним вртовима Нешто је директнија веза са проблематиком кровних вртова код критеријума везаног за употребу ефикасних инсталација водовода и санитарних арматура (Wat 04:Water Efficient
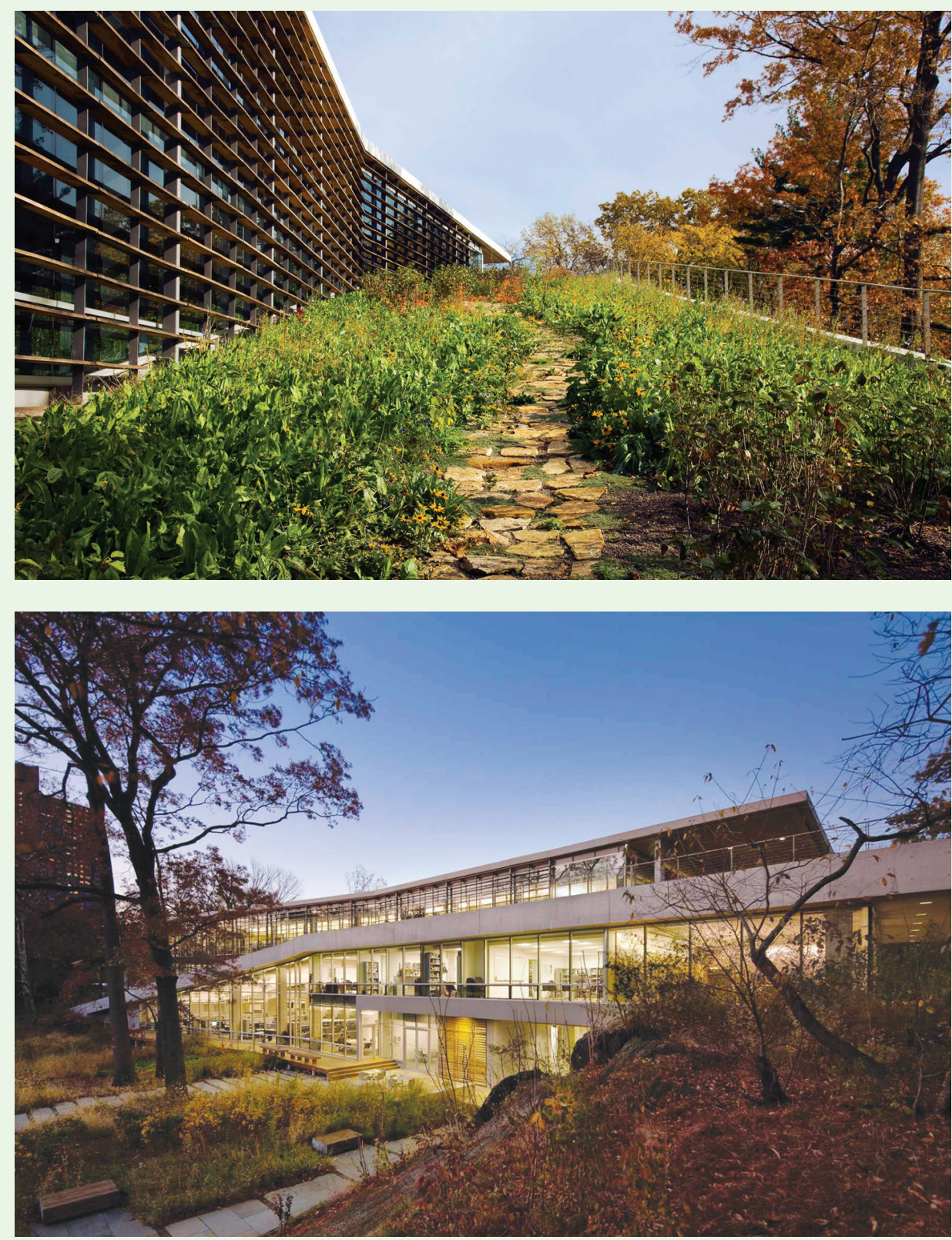

Сл. 4 и 5

Центар за глобалну заштиту дивљих животиња, Зоолошки врт у Бронксу, LEED златни сертификат

Fig. 4 and 5 .

Center for Global Conservation, Bronx Zoo campus, LEED-Gold certified

\footnotetext{
Екстензивни кровни врт користи плитак супстрат од 3-15 cm и представља лакши и јефтинији систем од интензивног кровног врта и првенствено се користи као еколошки кровни покривач. Проходност је ограничена или није дозвољена. Користе се биљке плитког корена: то су обично биљке ниског раста, покривачи тла и биљке које су толерантне на високе температуре, сушу, ветар и мраз. Формиран биљни покривач није захтеван за наводњавање, прехрањивање и одржавање, изузев у првој години (Sekulić, 2013).

4 Center for Global Conservation, пројектни биро FXFOWL, http://www.fxfowle.com/projects/4/Center\%20for\%20Global\%20Conservation/
} 
Equipment), у ком се третира и наводњавање кровних вртова, а правилан избор вегетације (која добро подноси сушу) и употреба кишних сензора на опреми за заливање наводи се као један од захтева за освајање одговарајућих поена за овај критеријум. Слично је и са категоријом Материјали и отпад, где постоји неколико критеријума кроз које је могуће вредновати одређене аспекте технологије кровних вртова, као што су Примењени изолациони материјали (Mat 01: Insulation) и Рециклиран агрегат (Wst 02: Recycled Agregates), кроз одговарајућ избор примењених материјала у складу са сертификацијом материјала и склопова које BREEAM систем подржава $a^{5}$. Као и код LEED-NC система, сматрамо да је акценат проблематике кровних вртова, ипак, ван ове категорије.

Највише критеријума који имају директну везу са кровним вртовима налази се у категорији Третман земљишта и екологија (Land Use \& Ecology). Један од њих је и Ублажавање еколошког утицаја (LE 03: Mitigating ecological impact), кроз који се квалитет решења вреднује путем индикатора биодиверзитата који се израчунава на основу заступљености различитих типова вегетације изградње. Опционо је, али се препоручује, ангажовање професионалног еколога (Suitably Qualified Ecologist, SQE) на основу чијег извештаја о типовима вегетације се израчунава тражени индикатор. Овим путем могу се освојити максимална 2 поена за овај критеријум, док је барем један обавезан. Критеријум Побољшаюье еколошких карактеристика локације (LE 04:Enchancing site ecology) је описног карактера и заснива се на ангажовању професионалног еколога (SQE) као члана пројектног тима, чији је задатак састављање плана очувања и побољшања еколошких карактеристика на локацији и њихово спровођење. За испуњење овог критеријума могуће је освојити до 3 поена, који се освајају ако се све предложене стратегије спроводе по плану и резултују повећањем 6 или више биљних врста на локацији након изградње.

У категорији Загађењь (Pollution), постоји критеријум Одлив атмосферских вода (Pol 03) за који нема обавезних захтева, а могуће је освојити максималних 5 поена. У оквиру овог критеријума кровни вртови нису посебно третирани.

\section{Критеријуми CASHBEE система релевантни за проблематику кровних вртова}

У склопу критеријума за смањење утицаја топлотних острва, који се вреднују кроз категорију Утицај на непосредно окружене (LR3: Off-Site Environment: Consideration of Local Environment), побројане су бројне стратегије са одговарајућим начином вредновања, као што су: позиционирање зграде тако да не представља препреку струјању ваздуха, избор фасадне облоге, моделовање којим се доказује утицај на смањење температуре на локацији и сл. Међу овим стратегијама вреднује се и избор кровног покривача, где је могуће освојити до максималних 3 поена за решење преко $40 \%$ кровне површине кровним вртом. Максималним испуњењем свих критеријума могуће је освојити укупно 27 поена, а за највиши ниво сертификације потребно је преко 20 поена у овој категорији, што само говори о значају проблема топлотних острва у Јапану и комплексном приступу његовом решавању.

Утицај кровних вртова на енергетску ефикасност вреднује се на сличан начин као и у претходна два описана система, кр0з свеукупне уштеде у складу са одговарајућим стандардом (JSBC, 2011: 175), у склопу критеријума Енергетске потребе зграде (LR1: Energy: Building Thermal Load).

Највише критеријума везаних за проблематику кровних вртова налази се у категорији Отворени простори на локацији (Q3: Outdoor Environment on Site), у оквиру које се критеријуми Очување и креирање биотопа (Conservation \& (reation of Bitope) и Побољшане термичког комфора на локацији (Improvement of the thermal environment on site) директно односе на допринос кровних вртова одрживости понуђених решења. Упрвом се проценат и квалитет пејзажно урбаних структура на локацији вреднују са максималних 7, од укупно могућих 15 поена, а за највиши ниво сертификације потребно је преко 13 поена. Квалитет вегетације или биљног покривача се процењује на основу врсте, где се предност даје локалним врстама, као и могућности за пружање склоништа ситним животињама. Удругом критријуму се вреднује укупан проценат проходних кровних површина под вегетацијом или биљним покривачем, где се екстензиван кровни врт преко целе проходне површине вреднује са 3 поена, од укупно могућих 27 поена, док је за највиши ниво сертификације потребно преко 18 поена. Остале стратегије којима се могу освојити поени у овом критеријуму су: обрада површина у партеру, проценат партерних површина под сенком, положај зграде који омогућава проветравање локације, као и постављање спољних јединица HVAC уређаја на одговарајућу висину како би се избегло додатно загревање.

Критеријуми везани за проблематику уштеде воде не третирају аспект кровних вртова, док се одлив атмосферских вода третира кроз критеријум у истој категорији као и критеријум везан за смањење ефекта топлотних острва, а вреднује се кроз мерења којима се доказује смањење у односу на референтне границе одређене стандардима.

\footnotetext{
Green Guide представља базу података о еколошким карактеристикама материјала и конструктивних склопова и заснива се на методологији процене животног циклуса (LCA-Life Cycle Assessment) у склопу BREEAM система. Више информација доступно на: http://www.bre.co.uk/greenguide/podpage. jsp?id=2126

6 Broad habitat type су дефинисани типови вегетације у BREEAM систему, где је за сваки дата нумеричка вредност која одговара броју заступљених биљних врста (taxon richness), што чини основу израчунавања индикатора биодиверзитета којим се процењује еколошки утицај на локацији након изградње.

7 LR3: Off-Site Environment: Load on Local Infrastructure: Reduction of Rainwater Discharge Loads)
} 


\section{ЗАКЉУЧАК}

Иако Србија тренутно нема званични систем за сертификацију зграда, а процес увођења основних регулаторних мера, попут енергетских пасоша, је на самом почетку, на тржишту постоји знатно интересовање за сертификацију објеката. Недавно је додељен први сертификат ове врсте ${ }^{8}$, а неколико пројеката је у фази сертификације по LEED систему. Критеријуми који су директно везани за примену решења кровних вртова, и који су од самог почетка развоја система сертификације нашли своје место у њима, само говоре у прилог томе да се савремена зграда грађена по принципа одрживе изградње не може замислити без њих.

Све више критикован приступ проблему одрживог грађења, Тзв. „наношење мање штете” (do less harm) приметан је и у третирању кровних вртова. Оно што се данас сматра одрживим решењем за десет или чак пет година чиниће се уобичајеним. Кровни вртови будућности више ће наликовати на живе организме него на кровне конструкције по којима су засађене биљке (Hake, 2007). 3бог тога се иновације у третирању и решавању кровних вртова морају охрабривати, што је понекад јако тешко у склопу сложених и компликованих система процене као што су сертификациони системи. Сувише уско дефинисани критеријуми и њихова међусобна искључивост могу представљати препреку даљем развоју и креативним приступима третмана зелених кровова.

\section{Захвалница}

Овај рад је урађен у склопу научног пројекта ТР 36034 под покровитељством Министарства науке и просвете Републике Србије.

\section{Литература:}

Ansel, W., \& Appl, R. (2004) Future and sustainable green roofs in Germany, In

Greening Rooftops for Sustainable Communities, Proceedings of the Second North American Green Roofs Conference, Portland, Toronto, The Cardinal Group

BREEAM. New Construction Non-Domestic Buildings Technical Manual SD5073 - 2.0: 2011. Watford, United Kingdom: BRE Global; 2011. http://www.breeam.org/

Ding, G. (2008) Sustainable construction: The role of environmental assessment tools, Journal of Environmental Management, Volume 86, Issue 3, pp. 451-464.

Ebert, T., N. Eßig, G. Hauser, (2011) Green building certification systems, Institut für internationale Architektur- Dokumentation GmbH \& Co. KG - A specialist book from Redaktion DETAIL, Munich

Ignjatović, D., N. Cuković- Ignjatović, B. Stanković, (2011) Architectural design energy efficiency assessment methods for building design and renovations, Proceedings: Building Services \& Architecture 2011 International Conference, October 27-28. 2002, Belgrade, Serbia

Jovanović-Popović, M., S. Kosanović (2009) Selection of building materials based upon ecological characteristics: priorities in function of environmental protection, Spatium 20, pp. 23-27.
Jovanović-Popović, M., S. Samardžić, S. Kosanović, B. Marković, (2008) Unapređenje energetske efikasnosti gradova / zgrada kroz proces energetske sertifikacije, Međunarodni naučni skup: Održivi prostorni razvoj gradova, Beograd, 25-26. januar 2008, Tematski zbornik radova: drugi deo, Beograd, Institut za arhitekturu i urbanizam Srbije, str. 229-240.

JSBC. Comprehensive Assessment System for Built Environment Efficiency (CASBEE) for New Construction Assessment Manual: 2010 Edition. Tokyo, Japan: Japan Sustainable Building Consortium; 2011. http:// www.ibec.or.jp/CASBEE/english/

Köhler, M., Wiartalla, W., and Feige, R. (2007). Positive interaction between PV-systems and extensive green roofs. Green Roof Infrastructure Monitor, 9, 1. Pp 14-15.

Larsson, N. (2000) Green Building: An Overview. http://fmv.fcm.ca/files/ Capacity_Building_-_MBRG/GB_policy_may_En.pdf pristupljeno 07.09.2011.

Papadopoulos, A. M. and Giama, E. (2007) Rating systems for counting buildings environmental performance, In: M. Santamouris and P. Wouters (eds.) Proceedings of the 2nd PALENC conference and 28th AIVC conference - building low energy cooling and advanced ventilation technologies in the 21st century, PALENC 2007, 27-29 September, CRETE Island, Greece, pp. 754-758.

Sekulić, M. (2013) Razvoj i transformacije krovnog vrta od nastanka do danas i njegova savremena primena, Doktorska disertacija, Novi Sad: FTN - Departman za arhitekturu i urbanizam

USGBC. LEED Reference Guide for Green Building Design and Construction: For the Design, Constructions and Major Renovations of Commercial and Institutional Buildings Including Core \& Shell and K-12 School Projects: 2009 Edition. Washington DC: US Green Building Council; 2009. http://www.usgbc.org/leed

Hake, A. (2007) Promoting sustainable green roofs through Leadership in Energy and Environmental Design (LEED), Department of Landscape Architecture, University of Missouri - Columbia

Cole, R. (2003) Building Environmental Assessment Methods: A measure of Success, Int. Electr. J. Construct, Special Issue on the Future of Sustainable Construction

Crčević, T. I Sekulić, M. (2012) Zeleni krovoi u kontekstu klimatskih promena - pregled novih iskustava, Arhitektura i urbnanizam, br. 36, Beograd

Wu, P., S. P. Low, (2010) Project Management and Green Buildings: Lessons from the Rating Systems, Journal of professional Issues in Engineering Education and Practice

Wen, Y. C. (2005) Comparison of two sustainable building assessment tools applied to Holmen project in Stockholm, Master of Science Thesis in Built Environment Analysis, Stockholm, Royal Institute of Technology

Извори илустрација:

Сл.1: http://leadingleed.com/tag/energy-and-atmosphere/

Сл. 2: http://www.ibec.or.jp/CASBEE/english/methodE.htm

Сл.3:Сл. 3: http://pichapuch.wordpress.com/2013/02/09

Сл. 4 и 5: http://www.fxfowle.com/projects/4/Center\%20for\%20Global\%20Conservation/

8 http://www.sam.org.rs/sr/actuelles/Novosti+iz+lzvr\%C5\%A1ne+kance larije/story/717/BLUE+CENTER+-+PRVA+ZELENA+ZGRADA+U+SRBIJI. 